\title{
Prevalensi Bakteri Coliform pada Susu Kedelai yang Dibeli dari Penjual Lokal di Surabaya, Indonesia
}

\section{The Prevalence of Coliform Bacteria in Soybean Milk Purchased from Local Sellers in Surabaya, Indonesia}

Firdaus, D. Z. B ${ }^{1}$, Indriati, D. W'1, Diyantoro' ${ }^{1}$ Sundari, A. S1*

${ }^{1}$ Antimicrobial Resource Alternative Studies for Emerging and Re-emerging Infectious Disease Research Group, Division Medical Laboratory Technology Department of Health, Faculty of Vocational Studies, Universitas Airlangga, Surabaya 60286, East Java, Indonesia

*email: aliyah.sundari@vokasi.unair.ac.id

\begin{abstract}
ABSTRAK
Susu kedelai diolah dari ekstrak kedelai. Susu kedelai terkenal di kalangan orang yang intoleransi terhadap produk susu. Penelitian ini bertujuan untuk memverifikasi higienis dan keamanan susu kedelai yang disiapkan oleh penjual lokal. Penentuan keberadaan mikroba dalam 30 produk susu kedelai menggunakan teknik streak plate dengan media agar MacConkey. Identifikasi bakteri dikonfirmasi dengan uji biokimia menggunakan uji triple sugar iron, uji indol, uji sitrat, uji metil merah, uji voges proskauer, uji motilitas. Dari 30 sampel, 40\% sampel terkontaminasi bakteri coliform. Di antara mereka yang terkontaminasi coliform, 3\% terkontaminasi Escherichia coli dan 40\% terkontaminasi Enterobacter. Implikasi dari penelitian kami adalah kualitas produk susu kedelai dari penjual lokal perlu dipantau untuk menghindari penularan infeksi ke pembeli. Oleh karena itu, penyuluhan tentang higienis dan keamanan produksi pangan akan diperlukan untuk memastikan produk susu kedelai bebas dari mikroorganisme patogen di masa mendatang.

Kata kunci: coliform, kontaminasi, susu kedelai, Escherichia coli
\end{abstract}

\begin{abstract}
2020. Firdaus et al. Open access under CC BY - SA license, doi: 10.20473/mkh.v31i2.2020.85-96 Received: 16-08-2020, Accepted: 14-092020, Published online: 29-09-2020

Available at https://e-journal.unair.ac.id/MKH/index
\end{abstract}


Soymilk was processed from extracted soy. Soymilk is well known among people who were intolerance with a milk product. This study aim is to verify hygienic and safety of the soymilk which was prepared by local sellers. The microbial presence in 30 soymilk products were determined using the streak plate technique with MacConkey agar medium. Bacterial identification was confirmed with a biochemical assay using triple sugar iron test, indol test, citrate test, methyl red test, voges proskauer test, motility test. Among 30 samples, $40 \%$ of samples were contaminated with coliform bacteria. Among those contaminated with coliform, 3\% contaminated with Escherichia coli and 40\% contaminated with Enterobacter. The implications from our study is that the quality of soymilk product from local sellers need to be monitored to avoid transmission of infections to the buyer. Thus, counselling about hygienic and safety of food production will be necessary to ensure soymilk products free of pathogenic microorganisms in the future.

Keywords: coliform, contamination, soymilk, Escherichia coli

\section{INTRODUCTION}

Soy is a type of legume indigenous to eastern Asia. Soy itself becomes an essential part of Asian diets. There are many kind of soy product including soy flour, soy protein, tofu and soymilk. Soymilk is suitable for consumption since it has high nutrition and it is considered as substitutions for cow`s milk, especially for that lactoseintolerant population (Adeleke, 2000). Soymilk mainly is a high source of protein, polyunsaturated fatty acids, carbohydrates and dietary fibers
(Brouns, 2002). Soymilk naturally contains isoflavones, that help lowdensity lipoprotein (LDL) cholesterol and thus will help reduce Cardiovascular Disease risk (Ramdath, 2017; Ofoefule, 2002). Other studies also reported its potential of isoflavones to protect against prostate cancer, breast cancer, uterine cancer, testicular cancer and other-hormone dependent cancers also osteoporosis (Patisaul, 2010).

Since soymilk contain high nutritional content, it can also suitable as a medium for bacterial growth. Thus it 
can enhance the probability for borne disease (Adeleke, 2000). Product contamination can be prevented and restricted by controlling microorganisms from contaminating the product with good handling and manufacturing practice (Ofoefule, 2002). Lack of hygienists and good sanitation from local sellers who produce soymilk will affected in soymilk contamination. The recent increase in soymilk consumption has encourage several large-scale and homemade based industry to also produced packaged soymilk. Thus, it is important to monitor hygiene and quality of soymilk.

\section{MATERIAL AND METHODS}

Samples: Thirty soymilk samples were collected from 30 local markets in Surabaya. All samples were transported in sterile plastic bottle container to Department of Medical Microbiology, Faculty of Medicine, Universitas Airlangga in portable insulated cold boxes. All samples were directly processed and analyzed within 24 hours.

\section{Isolation and Identification}

\section{Inoculation on MacConkey Agar}

One loopful of soymilk were streak into MacConkey Agar (Oxoid Ltd, UK). Incubation for all samples were done in incubator for $24 \mathrm{~h}$ in $37^{\circ} \mathrm{C}$. Inoculation in MacConkey to detect lactose - fermenter bacteria and non-lactose-fermenter bacteria (pink appearance) (Grainger, 2016).

\section{Gram Staining}

Gram staining were used to confirm gram negative bacteria. A heat-fixed smear of selected colony from MacConkey agar was made on a sterile slide and flood air-dried with crystal violet stain for one minute. This slide was rinsed with water for two seconds. Then soaked this slide with Iodine for one minute. The slide was rinsed as previous procedure then decolorized drop-wise with acetone alcohol for 15 seconds. After which the slide was washed then soaked with safranin, as a counterstaining stain for 30 seconds to one minute. This slide was rinsed in a slow running of water until no color appears. This slide then dried with absorbent paper. After this slide dried, 
immediately observed under magnification X100 using immersion oil (Gephart, 1884). After inoculation in Mac Conkey Agar, separated colonies were inoculated in Nutrient Agar Slant for further process

\section{Biochemical Test}

\section{Triple Sugar Iron Test (TSI Test)}

One loop of colonies from NAS were then inoculated in TSI Agar (Merck, Germany). Then incubated in incubator $37^{\circ} \mathrm{C}$ for 24 hours. Positive result for glucose, lactose and sucrose fermentation will be visualized with Acid/ Acid reaction in butt and slant part of the media. If $\mathrm{H}_{2} \mathrm{~S}$ is produced, the black color of ferrous sulfide will also be seen (Cain, 2013).

\section{Motility Test}

One loop of colonies from NAS were then inoculated in Motility Test (Becton and Dickson Co, USA) contain TTC (triphenyl tetrazolium chloride) (Merck, Germany) to facilitate the detection of motility. Incubation will be performed in incubator $37^{\circ} \mathrm{C}$ for 24 hours (Cain, 2013).

\section{Citrate Test}

Citrate test were performed using Simmon`s citrate Agar (Merck, Germany). Incubation were done in incubator $37^{\circ} \mathrm{C}$ for 24 hours. Bacteria that utilize citrate as their only carbon source will turning to blue colonies (Cain, 2013).

\section{Methyl red (MR) and Voges Proskauer}

\section{Test}

For MR and VP test, one loop of colony will be inoculated in Methyl red and Voges-Proskauer broth (Merck, Catalogue Number 1057120500). The bacteria that result in performs mixed acids fermentation will turn red after addition of methyl red. While bacteria that produce acetoin as end product will turn red after addition of alpha napthol $5 \%$ and potassium hydroxide $40 \%$ (Cain, 2013).

\section{Indole Test}

One loop of colonies from NAS were then inoculated in pepton water $1 \%$. Positive result when indole reacts with Kovac's reagent, it will be developed in the surface of media. Organisms can 
break down the amino acid tryptophan to indole (Cain, 2013).

\section{Urease Test}

Urease test were performed using Urease Agar (Merck, Germany). Incubation were done in incubator $37^{\circ} \mathrm{C}$ for 24 hours. Positive result for urea will be visualized with pink color in slant of the media. Bacteria which can hydrolyses urea produces ammonia and $\mathrm{CO}_{2}$. This end product can be detected will cause the color change of media which then will be detected by phenol red. The $\mathrm{pH}$ indicator, phenol red will detect the color change from light orange to magenta (pink) (Cain, 2013).

\section{RESULTS}

\section{Lactose Fermenter Bacteria were} dominantly found in Soymilk

Among 30 samples collected, nineteen samples were contained gram negative bacteria (63\%) which growth in MacConkey Agar (Table 1). All gram negative bacteria grow in Mac Conkey agar were lactose-fermenter bacteria group which can be seen as pink colonies. While 11 samples were negative without colonies growth in MacConkey Agar.

\section{Gram Negative were dominantly}

\section{found in Soymilk}

Gram staining were performed directly after samples were brought to laboratory. Thirteen samples were gram negative rods while the rest samples (6 samples) were gram negative coccus. Microscopic characteristics of all isolates were seen in table 1 . Thirteen samples were then inoculated in MacConkey agar and further process for biochemical test to identify coliform bacteria.

Table 1. Macroscopic and microscopic characteristics of the isolates

\begin{tabular}{llcc}
\hline & Characteristic & Inference & N sample (\%) \\
\hline Macroscopic & Colour: pink & Lactose-fermenter & $19(63.3)$ \\
& Shape : circular & & \\
& Texture : smooth & & \\
& Opacity: opaque & & \\
& Edge: entire & & $11(36.7)$ \\
\cline { 2 - 4 } & - & No bacterial growth & $6(20.0)$ \\
\hline Gram staining & Shape: coccus & Coccus Gram-negative & 6
\end{tabular}

2020. Firdaus et al. Open access under CC BY - SA license, doi: 10.20473/mkh.v31i2.2020.85-96 Received: 16-08-2020, Accepted: 14-092020, Published online: 29-09-2020

Available at https://e-journal.unair.ac.id/MKH/index 


\section{Colour: red}

$\begin{array}{ll}\text { Shape: rod } & \text { Rod Gram-negative } \\ \text { Colour: red } & 13(43.3)\end{array}$

\begin{tabular}{lll}
\hline- & No bacterial growth & $11(36.7)$
\end{tabular}

Enterobacter sp. were found Simmon's citrate test, Urease test, dominantly in Soymilk $\mathrm{MR} / \mathrm{VP}$ test. We found that Enterobacter

Thirteen samples contained rod sp. were found in 12 samples while gram negative bacteria were subjected for TSI test, Indol test, Motility test, Escherichia coli was found in 1 sample Table 2.

Table 2. Biochemical characteristics of rod Gram-negative bacteria present

\begin{tabular}{llcc}
\hline & Characteristic & Inference & N sample (\%) \\
\hline Biochemical test & TSI test: *A/A, no gas, no $\mathrm{H}_{2} \mathrm{~S}$ & Enterobacter $s p$. & $12(39.7)$ \\
result & Indol test: negative & & \\
& Motility test: positive & & \\
& Citrate test: positive & & \\
& Urease test: negative & & \\
& MR test: negative & & \\
VP test: negative & & \\
& TSI test: *A) A, no gas, no $\mathrm{H}_{2} \mathrm{~S}$ & Escherichia coli & \\
& Indol test: positive & & \\
& Motility test: positive & & \\
Citrate test: negative & & \\
Urease test: negative & & \\
MR test: negative & & \\
VP test: negative & & \\
\end{tabular}

*A/A: Acid/Acid

\section{DISCUSSION}

Our result showed that several soymilks has been contaminated with gram negative bacteria. A total of $63 \%$ samples were found Gram-negative bacteria contamination with dominant microorganisms found were rod Gramnegative bacteria $(43.0 \%)$ in the coliform group include Enterobacter sp (39.7\%) and Escherichia (3.3\%). Another study conducted by Agboke et al., (2012) 
showed tha

t Soymilk samples were also contaminated with coliform bacteria dominated by Escherichia coli, Enterobacter sp., and Klebsiella sp., while the coccus Gram-negative bacteria were not found. Several studies in other city in Indonesia also showed bacterial contamination especially Escherichia coli in Manado city (Habullah, 2015) and in Bukittinggi (Hilmari, 2018).

There were no contamination of Gram-positive bacteria on Soymilk samples in this study. Other research reported that not only Gram-negative bacteria contamination was found in Soymilk samples but also found Grampositive bacteria such as Bacillus subtillis, Bacillus cereus (Agboke, 2011), and Staphylococcus (Agboke, 2011; Thombarer, 2015).

Enterobacter and Escherichia are included in coliform bacteria groups. Coliform is a group of bacteria that is used as an incicator of fecal pollution and poor sanitation condition against water, food, milk, dairy products. The presence of coliform bacteria in food or beverage indicates the possibility of enteropathogenic miccroorganisms that are harmful to health (Irianto, 2013). The coliforms group can be found also in plants and the environment, thus, it indicate that positive coliform test does not necessarily pointed fecal contamination. Members of the genera Enterobacter, Serratia, Klebsiella, and others are classified as coliforms found in environment (Leclerc, 2001).

Among Enterobacteriaceae, the only microorganisms which can be a certain indicator for fecal contamination is Escherichia coli. Compared to other microorganisms, E.coli cannot survive outside intestinal tract of warm-blooded animals. While some species of Klebsiella, Citrobacter and Enterobacter can originate from both environmental sources or faecal matter. The presence of Enterobacter contamination was higher than E.coli show that the contamination did not originated from faeces but it could be contaminated by soil, insect, water, silages, farm produce, grass, silages, wooden reservoirs and fresh vegetables (Seidler, 1975).

Contamination found in soymilk 
product can be caused by contamination during processing, or packaging (Paramasatiari, 2018). Soymilk were process in several step, after soybean was drained then added with fresh water and boiled for 30 minutes. Soybean then was grounded with grinding made from metal or stone until pulp was formed. Boiling water was added to pulp then filtered with gauzed to obtain raw soymilk. Sugar and artificial flavor enhancer were then added to enhance the taste of soymilk (Koswara, 2009). Several source for contamination can be detected from this whole processing alone such as tools for grinding, container for soybean storage after grinding process and after filtering raw soymilk. Another source for contamination could be detected from contaminated raw materials, lack of good manufacturing practice (Liamngee, 2013) and coming from packaging process. Our study showed that monitoring the quality of soymilk produced by street vendors to ensure the high-quality soymilk and prevent infection from pathogenic bacteria.

\section{CONCLUSIONS}

Our study showed that there is coliform contamination found in soymilk sold by street vendors. Coliform found were $E$. coli and Enterobacter. This study urge that drinks sold by street vendors should be monitored to ensure safety and prevent infection from pathogenic bacteria.

\section{ACKNOWLEDGEMENT}

All authors wanted to thank Ms. Nani Nurhayati, for her supporting effort in helping to prepare all necessary step for microbial identification.

\section{REFERENCES}

Adeleke, O.E., Adeniyi B.A., Akinrinmisi, A.A. 2000. Microbiological Quality of Local Soymilk: a Public Health. Afr J Biomed Res. 2000;3:89-93.

Agboke, A.A; Osonwa, U.E.;Opurum, C.C. and Ibezim EC. Evaluation of microbiology quality of some soybean milk products consumed in Nigeria. Prime Resarch Med. 2011;1(2):25-30.

Brouns, F. 2002. Soya isoflavones: a new and promising ingredient for the 
health foods sector. Food Res Int. 2002;35(2-3):187-93.

Cain, D.; Hanks, H.;Weis, M.; Bottoms, C.;Lawson J. Microbiology Laboratory Manual. McKinney: Collin County Community College

Districts; 2013.

Gephart, P.; Murray, R.G.E.; Costilow, R.N.; Nester, E. W.;Wood, W.A.; Krieg, N.R.; Philips GB. Manual Methods for General Bacteriology. Washington D.C.: ASM Press; Washington D.C. (Gram C) (1884). Ueber die isolirte Farbung der Schizomyceten in Schnitt-und Trockenpraparaten, Fortschritte der Medcin, (2), pp. 185-189

Grainger, J. J. D. B. 2011. Basic Practical

Microbiology-A Manual. London:

Microbiology Society; 2016.

Habullah, Rumaidasari; Fatmawali;

Kojong N. Analysis of Coliform

Bacteria Contamination and

Escherichia coli soy milk sold in Supermarkets of Manado City. Pharmacon. 2015;4(1):20-31.

Hilmarni, Hilmarni; Satriani, R.; Rosi

DH. Uji Kontaminan Koliform

Susu Kedelai yang dijual di Pasar
Bawah Kota Bukittinggi.

Endurance. 2018;4(1):45-51.

Irianto, K. 2013. Medical Microbiology: Prevention, Food and Environment. 1st editio. Bandung: Alfabeta; 2013.

Koswara, S. 2009. Teknologi Pengolahan Kedelai (Teori dan Praktek). Jakarta: Pustaka Sinar Harapan; 2009.

Leclerc, H., Mossel, D. A., Edberg, S. C., Struijk, C. B. 2001. Advances in the bacteriology of the coliform group: their suitability as markers of microbial water safety. Annu Rev Microbiol. 2001;55:201-34.

Liamngee, K., Terna, T. P., Bem, A. A., Orpin, J. B., Mzungu, I., Obaje, M., Anum, I. 2013. Microbial analysis of soybean milk sold in Makurdi metropolius. IOSR J Environ Sci Technol Food Technol. 2013;3(3):97-104.

Ofoefule, S. 2002. A Text Book of Pharmaceutical Technology and Industrial Pharmacy. Samakun Nigeria enterprise; 2002. 120-125 p.

Paramasatiari, A. A. A. L. S. D. M. S. P. 
2018. Detection Escherichia Coli O157 contamination in soymilk from traditional market at Denpasar City Detection $\begin{array}{lll}\text { Escherichia } & \text { Coli } & \text { O157 }\end{array}$ contamination in soymilk from traditional market at Denpasar City. IOP Conf Ser MaterSciEng. 2018;434:0-5.

Patisaul, Heather, B. and Jefferson, W. 2010. The pros and cons of phytoestrogens. Front Neuroendocr. 2010;31(4):400-19. Ramdath, D. D., Padhi, E. M.T., Sarfaraz, S., Renwick, S., Duncan, A.M. 2017. Beyond the cholesterol-lowering effect of soy protein: A review of the effects of dietary soy and its constituents on risk factors for cardiovascular disease. Nutrients. 2017;9(4).

Seidler, R. J., Knittel, M. D., Brown, C. 1975. Potential pathogens in the environmental: cultural reactions and nucleic acid studies on Klebsiella pneumoniae from clinical and environmental sources. Appl Microbiol. 1975;29:819-25.

Thombarer, D.T.; Shende, R.T.; Nirgude, M. S.; Shinde, H. S. 2015. Microbiological analysis of soymilk produced from soybean. IOSR J Biotechnol Biochem. 2015;1(5):41-2. 